Fernando Carratalá Teruel

Universidad Complutense de Madrid

\title{
LA OBRA POÉTICA DE MIGUEL A. ARZOLA BARRIS
}

Miguel A. Arzola Barris nace en la localidad puertorriqueña de Yauco, el 1 de enero de 1958, hijo único del segundo matrimonio de su padre. Su temprana capacidad intelectual se fue cultivando en colegios católicos, en los que ya destacaba por su interés por la lectura y su amor a la palabra -oral y escrita-. «A los diez años -se retrata Arzola- era yo un niño normal, algo obeso, comilón, estudioso, cumplidor con las tareas académicas, poco colaborador en las tareas de la casa -porque otros se ocupaban de ellas-, amante de los patines y del balonvolea». Afectado, a esa edad, por el «síndrome Guillain-Barré» -que le deja casi paralizado, sin poder usar los músculos, y con graves dificultades respiratorias-, las terribles secuelas de la enfermedad le acompañan de por vida. Pero la férrea voluntad por superar, en la medida de lo posible su desgracias físicas -potenciada por su propia madre y por algunas de sus profesoras- le permitieron continuar con su formación - primero, en silla de ruedas; después, con abrazaderas en ambas piernas; más tarde, apoyado en un bastón...-; y así obtiene el título de Bachelor in Science en la Facultad de Ciencias Naturales de la Universidad de Puerto Rico (Río Piedras, mayo, 1982), y el título de Juris Doctor en la Escuela de Leyes de la Universidad Interamericana (San Juan, diciembre 1992). La vinculación con el mundo de la enseñanza ha sido una constante en Arzola, como maestro y como responsable de instituciones docentes del máximo prestigio. $\mathrm{Su}$ presencia en todo tipo de foros culturales le ha convertido en un referente intelectual de primer orden en Puerto Rico.

Las limitaciones físicas de Arzola -el caminar a veces le causa dolor y la pierna derecha se le va atrofiando cada vez más- poco inciden en su temperamento jovial; y su aspecto aparentemente depresivo - «la ropa que habitualmente visto es negra, y según pasan las tardes de los años de mi vida más oscuras son mis vestimentas»- exteriorizan más bien la melancolía de un espíritu renacentista. Su carácter cosmopolita le ha llevado a recorrer los países europeos de mayor tradición cultural -en viajes de estudio, más que meramente turísticos-, y su presencia en la madre patria -en la España cuya lengua tanto ama- es frecuente. No obstante, su mundo poético sí refleja una angustia existencial que impregna sus versos de hondo dramatismo, pero que está ausente en cualesquiera otras manifestaciones de su vida social y profesional.

\section{Tres etapas en la trayectoria poética de Miguel Arzola}

Arzola inicia su andadura poética en 1974, con la obra Poemas sin título-edición limitada en papel de $25,5 \mathrm{~cm}$ x $27,9 \mathrm{~cm}$-, que se difunde a través de las secciones culturales de periódicos, revistas literarias y antologías poéticas. A esta obra sigue la titulada Tres poemas y una canción, con la que el poeta obtiene el Primer Premio del Primer Certamen Literario de la Universidad de Puerto Rico -Río Piedras, 1975- y que, posteriormente, pasará a llamarse Mi voz y tres cantos. De 1976 es la obra Variaciones sobre un mismo tema -la edición se reprodujo usando estarcido, y se distribuyó por bibliotecas y entre las amistades de entonces, que hoy siguen vivas en el afecto del poeta-. La primera etapa de Arzola se cierra con la obra Desde mi adentro -de 1978-, coincidiendo con el inicio de la fascinación del poeta por la piedra. Todos estos «versos germinales»-al 
decir de Arzola- se publican en cuadernillos de papel engrapados al lomo en manera flexible.

La segunda etapa en la evolución poética de Arzola arranca con Piedras de este tiempo -de 1980, obra compuesta por 16 poemas, precedidos de una dedicatoria de 44 versos a Carmen Quiroga de Cebollero; «poesía interna e intensa», según la califica el poeta, que coincide con el descubrimiento de su fascinación por la piedra. Y de 1986 es la breve obra Variaciones, integrada por 13 poemas -en algunos de los cuales se alcanza un sugestivo clímax poético, como en los titulados «Eclosión de caminos» $\mathrm{y}$ «Ocaso interminable». (Variaciones, junto con Surcos en cuerpo de mujer -de Leira A. Santiago Vélez- y Pasionario -de Gerardo Torres Santiago- conforman Tres poetas yaucanos, que prologa Ramón Luis Acevedo). La siguiente obra de Arzola es Está la ventana rota -de 1999-, conjunto de 13 poemas a los que pone prólogo Manuel de la Puebla. (La obra se edita junto con Piedras de este tiempo, ahora prologada por Francisco Lluch Mora).

Y una tercera etapa -todavía abierta para bien de la poesía puertorriqueña- se abre con Desde lejos. Busco bajo la noche el silencio de las tinieblas (Mayagüez, Talleres de Antillian College Press, 2004; edición de 500 ejemplares; con prólogo de Loreina Santos Silva y epílogo de José Juan Báez Fumero), obra que toma su título del largo poema que la encabeza, al que siguen otros 38 poemas, y culmina con La tinta es sudario de la carne y la palabra..., la más larga de las obras de Arzola, con 40 poemas seguidos de un apéndice con otros dos.

\section{Influencias literarias}

Amigos y maestros inculcaron en Arzola, desde su infancia, el amor por la lectura, que se desarrolló plenamente en las aulas universitarias, bajo la fructífera orientación de la chilena Carmen Quiroga de Cebollero y de otros profesores que le acercaron al mundo de la literatura, de la mano de Juan Ramón Jiménez, Sábato, Cortázar, Sartre -«cuya obra teatral A puerta cerrada deja patente que el infierno que nos acompaña aquí en la Tierra es una realidad»-... Y en sus años universitarios Arzola empieza su formación humanista: se adentra en los secretos del teatro griego; asiste a las mejores representaciones dramáticas de aquella época -con actores de fama internacional- en el ámbito del Teatro Universitario; está presente en conciertos clásicos, óperas, zarzuelas; participa en tertulias literarias...; y, poco a poco, junto a su formación científica, va adquiriendo una concepción humanista de la existencia que, paradójicamente, se traduce en una vida cada vez más solitaria, siempre encerrado en sí mismo. El propio poeta explica con estas esclarecedoras palabras sus antecedentes literarios: «Mi identidad literaria es con todos y con el mundo. Decía Eugène Ionesco que Nunca se ha podido, con ayuda de las palabras, expresar todo lo que ocultan las palabras». Y, en efecto, son muchos los escritores y poetas que están presentes en la formación de mis versos y que han contribuido a dar vida a mis poemas, a sacar de mi interior cuanto conforma mi existencia, a dar paso al vértigo y a dejar desgarrada la garganta y a hacer que nazcan las palabras en mis manos. El grupo de amigos y presencias que me acompañan es inmenso; las influencias son, por lo demás, múltiples, pero la intención y la emoción son fenómenos atemporales, como lo es el hombre en su naturaleza misma -en su comienzo y en su constante repetición de caminos, de sentimientos, vacilaciones, ilusiones, fracasos... Es por ello que se han dado cita al convite de mis versos el Arcipreste de Hita -en alguna manera-, Quevedo y sus juegos de palabras, Sor Juana Inés de la Cruz, Gustavo Adolfo Bécquer -responsable de que me enamorara del verso cuando comenzaba la adolescencia-, Oscar Wilde y su Obscenidad crasa, 
Baudelaire, Mallarmé, Paul Valéry, Verlaine, Rubén Darío -y su Azul..., que me acompaña-, Juan Ramón Jiménez, el César Vallejo de Heraldos negros, Herman Hesse y su Lobo estepario, Gabriela Mistral, Borges, algo de Nietzche, y mucho de Neruda (aún estoy fascinado por las visita a la casa de la Isla Negra que Neruda tenía en Chile; y allí pude tocar las piedras, sentir las olas, ver la transparencia del cielo y los colores de la costa a la caída del sol... y caminar sobre la arena por la que anduvo el poeta)...» No son tantos, sin embargo, los escritores puertorriqueños que han influido en la trayectoria poética de Arzola: el transcendentalismo del yaucano Francisco Lluch Mora, Julia de Burgos, el trabajo de Báez Fumero, la motivación de Flavia Lugo de Marichal, la nueva poesía de Javier Ávila y de Noel Luna, Francisco Matos Paoli, Liliam Pérez Marchand, Violeta López Suria, Roberto Ramos Perea -de alguna forma-, Loreina Santos Silva y Colón Oliveri en Mayagüez, están presentes; «así como también lo están amigos y jóvenes escritores que en general caminan por la misma senda de lo que es fugaz, pues la palabra muere cuando se dice, porque es un juego con la forma, que a veces se encuentra en alguna librería, y la reconocemos, y la hacemos nuestra, y le damos vida para que muera nuevamente, porque son de todos las palabras y de nadie lo que se escribe en las piedras de la vida».

Conformando los temas actuales -iniciados con la tercera etapa de su poesía, desde 2004, el poeta se siente muy en la línea de Vicente Huidobro y de Luis Cernuda -cuyo padre nació en el municipio de Naguabo, en la zona este de la costa de Puerto Rico, desde donde marcha a España con motivo de su servicio militar-; y en completa empatía con Federico García Lorca y su Romancero gitano y el Llanto por la Muerte de Ignacio Sánchez Mejías, así como con Asunción Silva y su obsesionante poema «Nocturno». Por otra parte, el descubrimiento de las Memorias de Adriano -de Marguerite Yourcenar- sigue gravitando sobre el poeta. De los escritores norteamericanos, y por su temática, recibe el influjo de Walt Whitman y de Allan Poe, aunque se siente más cercano -«por su vuelo nostálgico»- de las sudamericanas Violeta Parra y Alfonsina Storni. Y, por supuesto, el poeta «levanta la copa de la inspiración» ante toda la monumental Generación del 27 española.

\section{Hacia una concepción poética personal}

Inmensa cultura literaria la de Arzola, pues, que desemboca en una poética personalísima: «Es en la poesía donde encuentro mis mayores mordiscos de felicidad; sí, la felicidad es de pequeños y grandes mordiscos que le arrancamos a la vida; y es de mordiscos la felicidad del camino existencial que a veces podemos llevar al espíritu o al cerebro; nunca de manera constante, pues siempre es mayor la tristeza y la desolación de la repetición de caminos y de viento. Y escribo y disfruto la poesía por sus imágenes espectaculares, poemas brevísimos y otros muy extensos, porque así es la paradoja y el conflicto mismo de la vida, en la que todos somos poema, palabra, luz, sombra y verso. [...] Escribir poesía en Puerto Rico - subraya Arzola- no es otra cosa que dar un salto al vacío - un Puerto Rico donde existen muchas limitaciones económicas, digan lo que digan los analistas financieros y aparenten los grandes proyectos desarrollistas; y donde el riesgo de no comunicar lo deseado está siempre presente- y tomar una decisión solitaria, extraña, íntima, personal; propia del decir que viene de adentro -al modo unamuniano-, frente al torrente social y socializante que nos viene de afuera, y ante el cual hay que triunfar o sucumbir. Son mis poemas lo que ocurre por dentro; son ellos mi punto de partida en el viaje de abordaje en el galeón de la vida. Para enfrentarme con lo que sucede afuera, mi campo de batalla y mis armas son mis palabras». Y es el propio poeta quien se sitúa ante la poesía con palabras que, por sí mismas, explican toda una forma de ser, de pensar y de sentir, y que 
justifican el hondo dramatismo de sus versos: «La tristeza, la soledad de estar entre la gente y ser como Garrick -el personaje poético de Juan de Dios Peza-, el pensarme cóndor que vuela hasta la cima de los Andes, o el sentirme pirámide en Perú, riachuelo en la hondonada de la selva de Horacio Quiroga, el intenar el juego que las gentes quieren cada día, ser piedra entre las piedras que no se quiebran, saberme gota de hielo que no se deshiela y luchar como Sísifo al modo de decir de Albert Camus, o saberme fuego eterno en la brutal angustia del Prometeo de la mitología griega. En mis palabras hay mucho de lo que es mi historia, del silencio en la sonoridad silenciosa de Delfos y de la ansiada tarea del vagabundo solitario que va en busca de su estrella fugaz cual misionero franciscano que llega en la barcaza del temible Aqueronte que es la vida y es la sombra hasta muchas orillas que son de muerte y de arena, de olas y peces, de escamas y espuma». (Estas y las anteriores citas están tomadas de la larga conversación personal mantenida con el poeta el 23 de julio de 2006, tras una reciente visita a Madrid).

\section{«LA TINTA ES SUDARIO DE LA CARNE Y LAS PALABRAS...»}

\section{La angustia existencial como trasfondo de una temática romántica}

Un tema recurrente marca el devenir de los poemas de Arzola: la frustración emocional, origen de una profunda desolación anímica. Arzola no pone sordina a la manifestación enérgica de su más recóndita y apasionada intimidad, y encuentra en el verso libre el cauce idóneo para dar rienda suelta a la expresión descarnada de sus estados anímicos presididos por el abatimiento, la desesperanza, la soledad buscada. Van surgiendo, así, poemas que son reflejo de una personalidad inconformista, de un «yo poético» en desacuerdo con el mundo circundante; unos poemas plenos de autenticidad -porque reflejan emociones intensamente vividas-, expresados con una insuperable densidad lírica. El «dolorido» sentir del poeta, la postura de saberse incomprendido, sus lamentos ante el penoso estado espiritual en que se halla inscriben su obra en la más pura tradición romántica: el influjo romántico lo es en la temática -el amor y la muerte, la soledad y la melancolía-, pero no en el lenguaje poético, personalísimo; como neorromántico es acudir, en este portentoso análisis introspectivo, a una naturaleza hosca, sumida en una aciaga oscuridad, y de la que están ausentes gratas sensaciones cromáticas y auditivas que pudieran mitigar el desasosiego que refleja, y que se erige -como manifestación de una realidad exterior hostil- en estandarte que exhibe la depresiva interioridad del poeta, siempre en busca de una plenitud vital perdida. En este marco referencial, promesas incumplidas, anhelos insatisfechos, decepciones profundas... van creando un trasfondo amargo que se acrecienta poema a poema, según avanza la obra, y que sólo la intensidad metafórica de la palabra poética es capaz de traducir con cierta garantía de veracidad. Y de ahí que Arzola, profundo conocedor de la riqueza léxica de la lengua española, esté en permanente pugna con el lenguaje de la comunicación ordinaria, que le resulta escaso para bucear en los laberintos de su alma, y obtenga en la irracionalidad del lenguaje poético el soporte indispensable para exteriorizar sus vivencias y sentimientos más subjetivos. No es, por tanto, casual, que algunos de los recursos estilísticos de tipo léxico-semántico empleados por Arzola -el oxímoron, la antítesis, la paradoja, la sinestesia audaz, la imagen onírica...- estén presentes -salvadas las enormes diferencias conceptuales- en los versos de San Juan de la Cruz, el poeta que aspira a verter en el insuficiente lenguaje humano lo inefable de sus procesos místicos de origen divino. Los poemas de Arzola, en definitiva, combinan felizmente el romanticismo inconformista y el sobrecogedor intimismo lírico 
-propio de Luis Cernuda-; el arrebato pasional marcado con el sello inconfundible de la sinceridad -tan característico de Miguel Hernández-; la riqueza verbal manifestada a través de sorprendentes metáforas -que en ocasiones recuerdan las imágenes cósmicas del mejor Pablo Neruda-; y la exuberante belleza de su lenguaje, que halla adecuada expresión en el verso libre, dramático y majestuoso -que Arzola domina con la perfección de Vicente Aleixandre. Porque Cernuda, Hernández, Neruda, Aleixandre... son sólo referencias literarias en la formación intelectual del poeta. Porque si por algo se caracteriza la poesía de Arzola es por su originalidad, tanto en la temática -esa falta de pudor tan adolescente con que abre las puertas de su yo más intimo- como en la forma de expresión -en la que la amplitud de recursos artísticos empleados refleja una personal interpretación de la Estilística convencional, dominada con pasmosa facilidad. Y junto a la originalidad, la poesía de Arzola rezuma intenso humanismo, capaz de conmover a los más variados lectores, subyugados por su autenticidad. Nada de extraño tiene, pues, que quienes se adentran en la poesía de Arzola le confieran una posición de privilegio entre las actuales -y escasas- voces líricas puertorriqueñas.

\section{Temática, génesis y estructura de la obra}

Conforman el libro 40 poemas «recreados en la soledad de mi recinto, en mi habitación; y a veces tarde, muy tarde, a solas, en mi lugar de trabajo; y siempre cuando me envuelve el ánimo oscuro e implacable de la existencia que me aguarda. En ocasiones voy al mar, lo escucho, y se me mete por dentro el rumor de olas; y también el olor a tierra y a montaña cuando recorro la Isla. Y así, lo absorbo en mi interior, y estalla frente a la amarilla página en blanco, con la estilográfica en la mano, a cualquier hora, ya en mi sancta sanctorum cuando llega el momento del parto del verso». Estos 40 poemas están agrupados en dos partes, en razón del momento de su composición, lo que origina, además, dos modalidades estilísticas diferentes de concebir la estructura poemática desde el punto de vista métrico. La primera parte -poemas 1 al 30- se compone entre abril y julio del 2005. Aparentemente, el poemario está terminado y tiene ya título. Sin embargo, en julio de 2006 el poeta añade una segunda parte que integran otros diez poemas, emocionado por las perspectivas de un viaje de perfeccionamiento profesional a España en el verano del 2007, y ante la certeza de que sus versos verán la luz en edición crítica y de que «no regresarán para siempre a la gaveta oscura». La cercanía de ambos acontecimientos, que aportan grandes dosis de ilusión en la vida del poeta, le lleva a escribir dos nuevos poemas, que figuran recogidos en el apéndice 1, y que están fechados el 1 de enero -poema 41- y el 15 de abril -poema 42- de 2007. Todos los poemas son intimistas -a excepción del 17, que recoge retazos de las impresiones que en el poeta suscita la visita a la Plaza del Duomo, de Florencia; y del 22, durísima diatriba contra todo tipo de injusticias sociales-. Y están rematados por una epifonema -de 1, 2, 3 y hasta 4 versos- que cierra o concluye el contenido poemático, por lo demás, fácilmente deducible de los versos anteriores; epifonema en el que suele culminar el clímax poético. Y, como señala el poeta, «en todos los poemas hay angustia, amor que no se alcanza, obsesión de la palabra por la palabra y desde la palabra; un intento por pretender ser diferente, aun reconociendo que en el juego de la palabras no son muy diferentes unos poetas de otros cuando de sentimientos se trata. Lo que he intentado en este conjunto de poemas es algo así como lo que nos dice la poetisa Rosario Ferré: que cuando de ella nada quede, ha de quedar la palabra». El poeta emplea exclusivamente el verso no sujeto a rima ni a metro fijo y determinado. Un total de 610 versos componen la obra, considerados los 40 poemas del 
texto (559 en su conjunto) y el apéndice 1 (otros 51 versos). Y es el versículo sin rima ni metro fijo y determinado - aun cuando no constituya unidad de sentido- el cauce métrico para la expresión poética de Arzola. Los efectos rítmicos habrán, pues, de buscarse en la recurrencia de palabras e ideas, en la coordinación funcional de elementos de la misma categoría gramatical, en los paralelismos, en las enumeraciones caóticas, en la peculiar organización estructural de los contenidos poemáticos, etc., etc. Porque lo cierto es que este tipo de poesía no es «técnicamente» fácil de construir.

\section{La lengua poética de Arzola}

Los versos de Arzola sorprenden por la enorme cantidad de recursos estilísticos que emplea a la hora de formalizar lingüísticamente sus contenidos poemáticos; unos recursos aprendidos en la lectura cabal de las obras de los mejores escritores en lengua española -desde los líricos petrarquistas hasta los poetas de la Generación del 27, pasando por culteranos, conceptistas, postrománticos, modernistas...-, pero usados siempre con una pasmosa originalidad y una asombrosa maestría técnica, fruto de la más exigente elaboración literaria.

Y lo primero que llama la atención al leer los poemas de Arzola es, por una parte, la perfecta congruencia que existe entre las ideas expuestas y la forma en que están expresadas, es decir, la ajustada relación entre el plano del contenido y el plano de la expresión linguística; y, por otra, el conocimiento y dominio linguístico del autor, que se muestra a través del léxico empleado -rico y variado, apropiado, preciso, siempre correcto, cargado de sugerentes valores connotativos en su significación- y de una compleja y variada estructura sintáctica -con predominio de las construcciones hipotácticas, que exigen un hábil empleo de procedimientos de cohesión y de elementos de conexión, responsables de la lógica concatenación de los poemas-; todo lo cual confiere al estilo un cierto carácter retórico.

El discurso poético de Arzola, además, potencia la interdependencia entre los elementos de los diferentes planos linguiísticos (fonético-fonológico, morfosintáctico y léxico-semántico); y, de esta forma, las «articulaciones» particulares de cada nivel lingüístico se ordenan en una «red o diagrama» superior, originándose, así, desde el interior del mensaje, un profundo «haz de significados», perceptibles gracias a la constante interacción contextual, de manera que cada poema se convierte en una unidad indestructible de «forma-contenido». Basta con leer los ocho poemas seleccionados en la breve antología que reproducimos a continuación -a nuestro entender, unos de los mejores del libro- para comprobar el extraordinario ideolecto estético que ha puesto en pie Arzola, poseedor de un estilo artístico tan original como exclusivo, difícilmente imitable. Insistimos en ello: la adecuada interacción de recursos de todos los niveles lingüísticos convierte cada poema de Arzola en una unidad total de comunicación donde los planos del contenido y de la expresión se imbrican recíprocamente y constituyen un depurado ejemplo de coherencia y cohesión textual, al que no es ajeno la firme voluntad del poeta por alcanzar un estilo personal que aúne la inspiración -siempre feliz-con una técnica literaria -por lo demás excelente- que eleva los poemas a las altas cimas de la belleza formal más absoluta.

\section{Dos poemas comentados de la última obra de Arzola-Barris: «La tinta es sudario de la carne y las palabras...»}

De la última obra de Arzola-Barris, concluida a finales del verano de 2007 -en pleno traslado del poeta, por motivos profesionales, de Mayagüez a San Juan, en Puerto Ri- 
co-, hemos seleccionado dos poemas (números 31 y 34), que son lo suficientemente representativos de su quehacer poético. Los breves comentarios que los acompañan pretenden poner de manifiesto la perfección técnica de una poesía que emplea los mejores recursos literarios para efectuar una conmovedora introspección anímica de sorprendente capacidad comunicativa.

\section{Poema 31}

La lluvia mojada trae la voz inexistente, que es de abismos y de confuso insomnio polvoriento y sombrío, perdido en algún lugar del mundo.

La voz regresa incesante al cuerpo vivo de infiernos, prisionero de hierro y de fuego, en duermevela fiel e inalterable de escapularios antiguos.

Es inconcebible el castigo eterno del universo, que resurge en cualquier esquina y camina cabizbajo, agarrado de la mano del olvido, que transita entre húmedos abanicos de vientos ancestrales, cargado de silencios y cansados paraguas desvelados por intentar reivindicar sus desgastados cuervos en la inalterable ilusión inconclusa que busca devorar la palabra adolorida y la angustia desgarrada que aprisiona y calcina los arcones misteriosos de la tierra del recuerdo.

La voz pulverulenta del tiempo se libera como ceniza en los labios de los muertos aletargados, y es de murmullos y de martillos y de asedios, que buscan aplacar las sombras descarriadas que se enredan en los párpados que son de orquídeas mojadas de taciturna tristeza.

Es de tormentos la voz que regresa en un viaje sin retorno, cuando la fugacidad del tiempo la convoca al escenario atrincherado donde se unen la soledad y la arena /de los huesos en hilos de azabache y pétalos de crisálidas muertas, atropelladas en el lecho óseo del hueco de mis manos mudas, que anhelan remontar extraordinarios vuelos de palabras lúcidas e /inexplicables para sujetarla al infinito en la angustiosa marea de vidrio que azota los barcos sin rumbo en el mar transformado en cementerios que refleja mágicas lunas enloquecidas de tedio. 
Principia el intento inservible del recuerdo, inescrutable e inmenso, cuando vuelven las palabras precisas, sin acentos ni sonrisa, para habitar /en mi cuerpo en medio del ensueño azul del cuchillo de la muerte, y los aguijones deshojados de ilusiones adormecidas y sepultadas en la putrefacta soledad donde gime el silencio.

Pasa el tiempo, que es de arena y de espejos de arco iris rotos; es la voz de la forma aterradora la que inunda de lágrimas solitarias la emoción desesperada que llega hasta el fondo de la Tierra donde habitan las raíces frías, las lombrices muertas y los saltamontes sin geometrías ni formas, sólo la palabra demoníaca y descarnada; la palabra, por siempre perpetua, que golpea al caer el agua en la diáfana cascada de la noche que se extingue, que llora y resplandece cuando pasa el tiempo que ya no existe.

(Nace en mi carne el asombro del tiempo indiferente que se pierde en los cristales azogados de la noche.)

\section{Notas de lectura}

$1 \mathrm{El}$ vocablo pulverulenta (= en estado de polvo) aumenta la intensidad significativa del verso: La voz pulverulenta del tiempo.

2-3 Versos encabalgados en los que la adjetivación resulta tan lúgubre como acertada: que es de abismos y de confuso / insomnio polvoriento y sombrío, (repárese en el adjetivo confuso, que aporta una nota de inequívoca indefinición; así como en la leve sinestesia del verso 3: insomnio polvoriento y sombrío).

5-6 Sorprendentes y expresivas imágenes las contenidas en estos versos: La voz regresa incesante al cuerpo vivo de infiernos, / prisionero de hierro y de fuego, (repárese en la violenta antítesis del verbo 5: cuerpo vivo de infiernos; y en la construcción simétrica del verso 6, que origina un ritmo intenso: prisionero de hierro y de fuego).

14 La presencia del prefijo negativo in- (en las palabras inalterable e inconclusa), junto a la aliteración de la vocal $i$ y de las consonantes $l$ y $n$ originan un verso altamente expresivo: en la inalterable ilusión inconclusa que busca [...].

19 Contiene este verso una magnífica polisíndeton, que realza el valor semántico de los conceptos expresados: y es de murmullos y de martillos y de asedios. (Repárese, además, en la leve aliteración de las consonantes $m$ y $l l:$ y es de murmullos y de martillos).

22 Expresiva aliteración de $t$ la resultante de la combinación sintagmática taciturna tristeza.

25-27 La cuidada puntuación ortográfica de estos complejos versos «remansa y apacigua» su lectura. Por otra parte, la densidad metafórica del verso 27 es manifiesta; y la aliteración de las consonantes $m$ y $s$ aumentan la expresividad de aquélla: atropelladas en el lecho óseo del hueco de mis manos mudas. 
33 Otra sugestiva aliteración de la vocal $i$, a menudo formando sílaba con la consonante $n$ : Principia el intento inservible del recuerdo, inescrutable e inmenso, (repárese que, salvo en la palabra principia, que contiene la $i$ en sus tres sílabas, la combinación in- es un prefijo negativo).

34-36 La puntuación ortográfica facilita la comprensión de los versos: cuando vuelven las palabras precisas, [...] / y los aguijones deshojados [...]. El verso 35 incluye una sinestesia de corte tradicional -ensueño azul-, que en violento contraste con el resto de la imagen evocada, hace más desconcertante el contenido expresado: en medio del ensueño azul del cuchillo de la muerte.

37 Verso en el que el clímax poético alcanza su culminación, y que remata un eficaz oxímoron: en la putrefacta soledad donde gime el silencio.

42 Nueva aliteración de consonantes nasales, que contribuyen a hacer más enigmático e irracional -irracionalmente poético- el contenido del verso: las lombrices muertas y los saltamontes sin geometría ni formas.

Una vez considerado el poema en su totalidad puede comprobarse el elevado número de vocablos que contienen el prefijo -in, con el valor significativo de «negación o privación»: inexistente, insomnio (estrofa 1); incesante, inalterable (estrofa 2); inconcebible, inalterable, -empleado por segunda vez-inconclusa (estrofa 3); inexplicables, infinito (estrofa 5); inservible, inescrutable, inmenso (estrofa 6); indiferente (epifonema); en total, 12 vocablos diferentes. Podría tratarse de una selección léxica casual; aunque conociendo el dominio del léxico que define a Arzola, la casualidad deja paso a la necesaria búsqueda consciente de aquellos vocablos que mejor le sirven para ahondar en las profundidades de su ser.

\section{Comentario del poema 31}

Tremendo poema en el que la voz atormentada del poeta encuentra su cauce de expresión no a través de «palabras lúcidas e inexplicables»-verso $28-$, sino por medio de la «palabra demoníaca y descarnada»-verso 43- con la que sepulta pasadas ilusiones y recuerdos inalcanzables, y se sume en la más angustiosa soledad, entre lágrimas de desesperación que hacen incluso gemir al silencio -verso 37-. La selección léxica efectuada por Arzola -con adjetivos cargados de sugestivos valores connotativos- recalca insistentemente esa soledad que descompone el ánimo del poeta -la combinación sintagmática del verso 37 no puede ser más expresiva: putrefacta soledad- hasta límites insoportables, y provoca un estado de permanente ansiedad al que no son ajenas ciertas paradojas (La lluvia mojada trae la voz inexistente, -verso 1-; Es de tormentos la voz que regresa en un viaje sin retorno, -verso 23-) que hacen más patético el clima de desasosiego y desolación anímica que recorren el poema de principio a fin.

El poema está organizado en siete atípicas combinaciones estróficas de muy desigual extensión, rematadas por un epifonema, que suman un total de 48 versos, igualmente heterogéneos en cuanto a su numero de sílabas, y que se ajusta al siguiente esquema métrico: estrofa 1, de 4 versos, entre las 15 y las 9 sílabas; estrofa 2, de 3 versos, entre las 19 y las 10 sílabas; estrofa 3, de 9 versos, entre las 23 y las 9 sílabas; estrofa 4, de 6 
versos, entre las 21 y las 8 sílabas; estrofa 5, de 10 versos, entre las 25 y las 9 sílabas; estrofa 6, de 5 versos, entre las 27 y las 16 sílabas; estrofa 7, de 9 versos, entre las 21 y las 10 sílabas; epifonema final, de 2 versos encabalgados, de 15 y 16 sílabas, respectivamente. La irrupción del versículo crea un ritmo muy peculiar, ajeno a la reiteración de elementos fónicos -ya que la medida de los versos y las pausas son variables, y los acentos no se distribuyen con regularidad-, logrado con la reiteración de palabras y de estructuras sintácticas, así como con diferentes tipos de «paralelismos semánticos».

Por otra parte, el poema de Arzola es un buen ejemplo de lo que el académico -y poeta-Carlos Bousoño ha denominado dinamismo sintáctico expresivo negativo: el tipo de categorías gramaticales -con predominio absoluto de los adjetivos, que evitan una rápida progresión y propician una regresión hacia el nombre que matizan-, así como los tipos de oraciones empleadas -con predominio de la subordinación, que colorea negativamente el dinamismo de los verbos y origina una sintaxis lenta y morosa- ayudan a subrayar expresivamente los contenidos comunicados. Y, en efecto, la multiplicidad de adjetivos - ¡hemos contado hasta 60 , entre calificativos y participios con valor adjetival, en 48 versos!- y la presencia continua de oraciones de relativo -24, en total- introducidas por el pronombre que -en 21 ocasiones- y por el adverbio donde -en otras tres-confieren a la sintaxis un ritmo lentísimo, acorde con el propio contenido expresado en el poema.

Los adjetivos van mayoritariamente pospuestos - por lo general, uno; aunque a veces aparecen dos, e incluso hasta tres, como sucede en los versos 8 y 10: Es inconcebible el castigo eterno del universo, / [...] y camina cabizbajo, agarrado a la mano del olvido; verso este último en que los adjetivos tienen función predicativa, pues modifican, simultáneamente, al nombre castigo y al verbo caminar-; aunque hay siete casos de adjetivo antepuesto, en calidad de epíteto -húmedos abanicos (verso 11), desgastados cuervos (verso 13), taciturna tristeza (verso 22), extraordinarios vuelos (verso 28), angustiosa marea (verso 29), putrefacta soledad (verso 37), diáfana cascada (verso 45); y también simultanea el poeta anteposición y posposición, en construcciones sintagmáticas de sugestivos matices semánticos: confuso / insomnio polvoriento y sombrío (versos 2-3), cansados paraguas desvelados (verso 12), inalterable ilusión inconclusa (verso 14), mágicas lunas enloquecidas (verso 32); y hasta hay algunos casos de desplazamiento del calificativo: se libera como ceniza en los labios de los muertos aletargados, (verso 18); Pasa el tiempo, que es de arena y de espejos de arco iris rotos; (verso 38).

En ocasiones, las oraciones de relativo originan encabalgamientos oracionales, por estar situada la pausa versal después del antecedente, en una oración adjetiva especificativa; sirvan como ejemplo de sucesivos encabalgamientos oracionales los versos 19-22, en la cuarta estrofa: y es de murmullos y de martillos y de asedios / que buscan aplacar las sombras descarriadas / que se enredan en los párpados / que son de orquídeas mojadas de taciturna tristeza.

Toda esta intrincada «arquitectura sintáctica» se adecúa extraordinariamente al contenido expresado y origina un estilo retórico muy en consonancia con la complejidad de la ideación. Sin duda es este un poema en que expresión y contenido se ajustan de manera admirable; y el exceso de subjetivismo, que afecta tanto al contenido -con presencia de elementos estrictamente personales- como a la forma de tratarlo, no obstaculiza la comprensión por parte de lectores no especializados en el ámbito literario. 


\section{Poema 34}

Hay verbos irregulares y metáforas

en los embriones de mis versos

y el tacto de mis manos adormecidas

cuando el arte

de actitudes herejes descubre las sombras fantasmales

de los diminutos espectros

que se diluyen en el trasluz de mis ventanas.

Las cárcavas de mis versos son hondas y profundas, de color de estrellas dóciles y erráticas,

huérfanas de palabras que resuman

en los múltiples intersticios del abismo de la muerte

las imágenes de la voz exacta del Universo

que no se escucha en las herméticas paredes de mis ventanas.

Necesito las palabras que son pálidas y débiles, que se pierdan en la prontitud de la Luna

que apacienta los crepúsculos de las palabras inertes

que naufragan en los ínfimos aleteos de mis ventanas.

(Para arrebujarme de palabras sin excusa

no hace falta ubicar adjetivos y gramáticas de luces apagadas.)

\section{Notas de lectura}

5-6 La relación significativa de determinados vocablos favorece la cohesión textual y revela lo apropiado de la selección léxica operada por el poeta: de actitudes herejes descubre las sombras fantasmales / de los diminutos espectros.

$8 \mathrm{El}$ valor polisémico del esdrújulo cárcavas puede generar insospechados equívocos; además, las construcción son hondas y profundas potencia, de una parte, el «tartamudeo silábico»-son hondas-y, de otra, el juego fonético próximo a la paronomasia hondas/(prof)undas. Surge, así, un verso de enorme sonoridad: Las cárcavas de mis versos son hondas y profundas.

9 Continúa la sonoridad, ahora gracias a la coherencia de dos adjetivos esdrújulos consecutivos a final de verso: de color de estrellas dóciles y erráticas.

14 Igual que sucede en el verso 9, dos adjetivos esdrújulos consecutivos se encuentran situados al final del verso y recalcan sus respectivos significados: Necesito las palabras que son pálidas y débiles.

18 La significación del verbo arrebujarse (= cubrir bien y envolver con alguna prenda de vestir bastante amplia) confiere al verso una enorme expresividad: Para arrebujarme de palabras sin excusa. 


\section{Comentario del poema 34}

Poema de mensaje inequívoco: el tratamiento artístico de la palabra no necesita someter la inspiración poética al rigor formal de la lógica gramatical; sin embargo, el poeta pugna en vano por hallar las palabras adecuadas con que auscultar sus vivencias anímicas y manifestar su personal concepción de la realidad: palabras -sombras fantasmales, diminutos espectros, según metáforas reiteradas bajo diferentes formas léxicas de los versos 5 y 6 - que se difuminan (estrofa 1), que fracasan (estrofa 2), que sucumben (estrofa 3 ) en su intento por alcanzar su propósito comunicativo.

El poema, de 19 versos, está compuesto por tres agrupaciones estróficas -no sujetas a un canon prefijado-, de 7, 6 y 4 versos, respectivamente, y un epifonema de 2 versos. La heterometría vuelve a ser una constante, con predominio del versículo amplio que alcanza las 17 sílabas en la primera estrofa (verso 5), las 18 en la segunda (verso 13), las 19 en la tercera (verso 17) y las 22 en el verso 19, que cierra el epifonema con que concluye el poema.

Globalmente considerada la estructura del poema, llama la atención su profunda coherencia interna, que queda formalmente expresada por medio del verso con que concluyen las tres estrofas: de los diminutos espectros / que se diluyen en el trasluz de mis ventanas. (estrofa 1, verso 7); las imágenes de la voz exacta del Universo / que no se escucha en las herméticas paredes de mis ventanas. (estrofa 2, verso 13); que apacienta los crepúsculos de las palabras inertes / que naufragan en los ínfimos aleteos de mis ventanas. (estrofa 3 , verso 17). Adviértase, además, que todos los anteriores versos presentan encabalgamientos oracionales del tipo antecedente / relativo que: espectros / que se diluyen; la voz [...] / que no se escucha; las palabras / que naufragan. Esta sólida trabazón interna está, pues, basada en la idea recurrente de que el poeta se topa con serias dificultades para establecer una fluida comunicación que le sirva para asentarse en el mundo y reconocerse a sí mismo: las palabras se diluyen (verso 7), no se escuchan (verso 13), naufragan (verso 17) ante las simbólicas ventanas del poeta, que permanecen cerradas.

La profusión de adjetivos - 15 en total, en 11 de los 19 versos- ralentiza el ritmo de los versos -algunos ya de por sí bastante amplios-, que resulta solemne por momentos. Por otra parte, la casi docena de vocablos esdrújulos estratégicamente situados a lo largo del poema, hace más expresiva la rotunda sonoridad: metáforas (estrofa 1), cárcavas, dóciles, herméticas, huérfanas, imágenes, erráticas (estrofa 2), pálidas, débiles, crepúsculos, ínfimos (estrofa 3).

\section{PESNIŠKI OPUS MIGUELA A. ARZOLE BARRISA}

Poleg čudovitih literarnih postopkov in globokega čustvenega naboja verzov tega portoriškega pesnika, ki odsevajo poetično in resnično eksistncialno tesnobo, $v$ njegovem delu naredi poseben vtis «zven» španskega jezika, saj združuje moč naših najboljših klasikov in izostren občutek umetnika, ki liturgično časti svoje izrazno sredstvo. 